\title{
PRODUCTIVE AND REPRODUCTIVE PERFORMANCE OF RUSSIAN BLACK PIED COWS IN THE FIRST THREE LACTATIONS UNDER HOT CLIMATE CONDITIONS IN UZBEKISTAN
}

Oudah, E. Z. M.; M. A. Mostafa; M. N. El-Arian and Rehab F. S. A. Ismail

Dept. of Animal Production, Faculty of Agriculture, Mansoura University PC: 35516, Mansoura, Egypt. E-mail: saidauda@mans.edu.eg

\section{ABSTRACT}

Data on 1809 records of productive and reproductive traits in Black Pied cows were studied to determined the performance of these cows under hot-climate conditions in Uzbekistan Republic during the first three lactations and to analyze some genetic and environmental factors affecting these traits. The random effects studied were sire and dam within sire. The fixed effects were season of calving/birth (winter from October to March and summer from April to September), year of calving (1971 to 1983)/birth (1968 to 1981) and parity (1 to 3). Data were analyzed using linear mixed model least squares and maximum likelihood (LSMLMW) computer program of Harvey (1990). The overall mean ( \pm S.D) of total milk yield (TMY) was $4056 \pm 1112 \mathrm{~kg}$, $305-\mathrm{d}$ milk yield $(305-\mathrm{dMY})$ was $3860 \pm 959 \mathrm{~kg}$, fat percentage (FP\%) was $3.69 \pm 0.16$, lactation period (LP) was $307 \pm 58.4$ days, dry period (DP) was $79.3 \pm 37.7$ days, fat yield $(F Y)$ was $150 \pm 40.7 \mathrm{~kg}$, fat-corrected milk was $3865 \pm 1051 \mathrm{~kg}$, annualized milk yield was $3861 \pm 991 \mathrm{~kg}$, calving interval $(\mathrm{Cl})$ was $386 \pm 62.9$ days, days open (DO) was $103 \pm 63.1$ days and age at first calving (AFC) was $871 \pm 110$ days. Sire of the cow (father) had significant effect on all studied traits except on LP, DP and AFC. Year of calving/birth significantly affected all studied traits except on DP and FCM was not significant. On the other hand, season of calving/birth had insignificant effect on all traits. Parity had significant effect on all traits except LP and $\mathrm{Cl}$ did not affect significantly by parity. First parity cows had significantly lower TMY, 305-DMY, FP, FCM and AMY means than cows with more than parity. TMY in the $3^{\text {rd }}$ lactation was significantly higher than that in the $2^{\text {nd }}$ and $1^{\text {st }}$ lactation by 11.5 and $28.6 \%$, respectively (4689 VS 4205 and $3645 \mathrm{~kg}$, respectively). Each of $305 \mathrm{dMY}, \mathrm{FY}, \mathrm{FCM}$, and AMY followed the same trend of the TMY during the first three lactations. Therefore, more attention should be given to cows in the first parity in order to improve the productivity of the cows. Genetic improvement could be also achieved on these traits through sire selection.

\section{INTRODUCTION}

The Black Pied breed developed from crossing the local cattle in various areas with the Dutch Black Pied and East Friesian breeds. Pure breeding of Dutch cattle in Russia was conducted on only a small scale. The Central, Ukrainian, Siberian and other strains of Black Pied cattle were formed by absorptive and reproductive crossing (Dmitriev and Ernst, 1989).

The Black Pied breed is noted for high milk production (the highest among the dairy breeds), good conformation and good beef qualities. Due to the high productivity, adjustment to machine milking, well-defined beef features and the ability to acclimatize, the population of this breed is 
increasing year by year. By the beginning of 1980 the number of Black Pied cattle in the former USSR was 16449000 excluding the Baltic population. In numbers they are second (25.2\%) among 50 cattle breeds in the country (Dmitriev and Ernst, 1989).

The Black Pied breed comprises five large populations: Central (MidRussian), Baltic, Ural, Siberian, and other zones, namely Ukraine, Byelorussia, Central Asia, and parts of Transcaucasia. The animals of the Central group (where the animals of this study were lived in Uzbekistan, Central Asia) are the largest (live weight 550-650 kg), with a more compact conformation, relatively shortlegged and a good exterior appearance. This group is noted for the highest milk production $(5500-6500 \mathrm{~kg}$ ) with low butterfat content (3.6-3.7\%).

It is known that milk yield is the major trait of economic importance in dairy breeds. The yields of farm animals are the result of the combined effects of genotype and environmental conditions. In order to increase the yield level, it is necessary to optimize the environmental conditions and to improve the genetic structure of the animals.

In the same trend, Milk yield and reproductive traits are key traits in dual-purpose herds, because they have a direct effect on their productivity and profitability. Knowledge of the environmental factors that affect these traits can help the producer to establish better management programs. Improvement of productive and reproductive performance traits is an increasingly important breeding goal in dairy cattle and other livestock production systems.

Several workers have shown that productive and reproductive traits are heritable and they are greatly influenced by the genes which the dams and sires transmit to their progenies. Therefore it seems necessary to study the effect of sire on productive and reproductive traits (Petrovic, 1992, Ali, 1995 and Ali and El-Banna, 2001).

The objectives of the present study were to obtain estimates of productive and reproductive traits for Black Pied cows under hot-climate conditions in Uzbekistan Republic during the first three lactations and to evaluate the effect of some genetic and environmental factors on these traits.

\section{MATERIALS AND METHODS}

\section{Data}

Data on the productive and reproductive performance of 892 Russian Black Pied herds located in Chinaz, Uzbekistan, for the period 1968 to 1983 were used. The data were collected from records of Russian Black Pied cows belonging to Chinaz Farm located at Chinaz region (about $60 \mathrm{~km}$ west of Tashkent City, Uzbekistan Republic). The area of study is located between $40^{\circ} 56^{\prime}$ and $40^{\circ} 92^{\prime}$ north latitude and $68^{\circ} 44^{\prime}$ and $54^{\circ} 60^{\prime}$ east longitude. The climate of this region is hot. The monthly maximum temperature varies between $35^{\circ}$ and $45^{\circ} \mathrm{C}$. The total numbers of records during the first lactation (parity) were 819 , during the second lactation were 598 and during the third lactation were 392. Thus, the total number of records used in the present 
study were 1809. Data were distributed according to season of calving to two seasons, winter from October to March (771 records) and summer from April to September (1038 records). The corresponding figures for season of birth in case of age of first calving were 431 and 338 for winter and summer, respectively.

\section{The studied traits:}

The following productive traits were studied: Total milk yield (TMY, $\mathrm{kg}$ ), 305-day milk yield (305-dMY, kg), lactation period (LP, day), dry period (DP, day), fat percentage (FP\%), fat yield (FY, kg), fat corrected milk (4\%) (FCM, $\mathrm{kg}$ ). Annualized milk yield (AMY, kg). Fat corrected milk was calculated according to the formula of Gaines and Overman (1938): $F C M=\left(0.4^{*} \mathrm{TMY}\right)+$ $\left(15^{\star} \mathrm{FY}\right)$, where: $\mathrm{TMY}=$ total milk yield $(\mathrm{kg}), \mathrm{FY}=$ fat yield $(\mathrm{kg})$. Annualized milk yield was calculated according to Million and Tadelle. (2003): AMY= $(\mathrm{TMY} / \mathrm{Cl})^{*} 365$, Where: $\mathrm{TMY}=$ total milk yield $(\mathrm{kg})$, and $\mathrm{Cl}=$ Calving interval (days).

The following reproductive traits were studied: Calving interval $(\mathrm{Cl}$, day): was computed as the interval between the two successive calving. Days open (DO, day): was computed as the interval in days between the date of calving and the date of conception. Age at first calving (AFC, day), was computed as the difference between first calving date and date of birth.

Management: The main characteristics of this herd under study were described by Oudah (1996). Briefly, the general management of the herds is based on cows were milked twice daily at 6 am and $4 \mathrm{pm}$. Milk yield was recorded once each month in certain day for all cows (test day record). Monthly milk yield was calculated by multiple test day milk yield record by 30 days. Total milk yield during all lactation was calculated by summation of all monthly milk yields. The cows were dried off 2 months before the next calving or when its milk yield was less than $0.5 \mathrm{~kg} / \mathrm{milking}$. Cows were inseminated during the $3^{\text {rd }}$ or $4^{\text {th }}$ estrus after calving. Heifers were inseminated when its weight $350 \mathrm{~kg}$ or 18 months of age which comes first.

\section{Statistical analysis}

Data were analyzed using linear mixed model least squares and maximum likelihood (LSMLMW) computer program of Harvey (1990). Three models of statistical analysis were used for analyzing factors affecting productive and reproductive traits as follows:

The first mixed model was used to analyze productive traits, i.e. TMY, 305-dMY, LP, DP, FP, FY, FCM and AMY as follows:

$Y_{i j k l m n}=\mu+S_{i}+D_{j}\left(S_{i}\right)+S_{e}+Y_{1}+P_{m}+b L(X-X)+b Q(X-X)^{2}+e_{i j k l m n}(1)$ Where:

$\mathbf{Y}_{\mathrm{ijklmn}}=$ dependent variable $(\mathrm{TMY}, 305-\mathrm{dMY}, \mathrm{LP}, \mathrm{DP}, \mathrm{FP}, \mathrm{FY}, \mathrm{FCM}$ and AMY),

$\mu=$ the generalized least squares mean,

$\mathbf{S}_{\mathbf{i}}=$ the random effect of the $i^{\text {th }}$ sire, 
$\mathbf{D}_{\mathrm{j}}\left(\mathbf{S}_{\mathrm{i}}\right)=$ the random effect $\mathrm{j}^{\text {th }}$ dam within the $\mathrm{i}^{\text {th }}$ sire,

$\mathrm{Se}_{\mathbf{k}}=$ the fixed effect of the $\mathrm{j}^{\text {th }}$ season of calving (winter $=1$, summer $=2$ ),

$Y_{I}=$ the fixed effect of the $\mathrm{Ith}^{\text {th }}$ year of calving $(1971,1972,1973 \ldots$ and 1983),

$P_{m}=$ the fixed effect of the $m^{\text {th }}$ parity,

$\mathbf{b L \& b Q}=$ partial linear and quadratic regression coefficients, respectively for productive traits on days open (day), $\mathbf{X}=$ day open (day) of cow, $X_{1}$ average days open (days); and

$\mathbf{e}_{\mathrm{ijklmn}}=$ residual error assumed as random .

2. The second mixed model was used to analyze reproductive traits i.e. $\mathrm{Cl}$ (day) and DO, (day) as follows:

$Y_{i j k l m n}=\mu+S_{i}+D_{j}\left(S_{i}\right)+S_{e}+Y_{1}+P_{m}+b L(X-X)+b Q(X-X)^{2}+e_{i j k l m n}(2)$

where all definitions as mentioned in equation (1) except for:

$\mathbf{Y}_{\mathrm{ijk} k \mathrm{mn}}=$ dependent variable $(\mathrm{Cl}$ and $\mathrm{DO})$,

$\mathbf{b L \& b Q}=$ partial linear and quadratic regression coefficients, respectively for reproductive traits on TMY, $\mathbf{X}=$ TMY $(\mathrm{kg})$ of cow, $X_{1}$ average TMY $(\mathrm{kg})$.

3. The third mixed model was used to analyze age at first calving (day) as follows:

$\mathbf{Y}_{\mathrm{ijkm}}=\mu+\mathbf{S}_{\mathrm{i}}+\mathbf{S e}_{\mathrm{j}}+\mathbf{Y}_{\mathrm{k}}++\mathbf{e}_{\mathrm{ijkm}}$

Where:

$\mathbf{Y}_{\mathrm{ijklm}}=$ dependent variable (AFC),

$\mu=$ the generalized least squares mean,

$\mathbf{S}_{\mathbf{i}}=$ the random effect of the $i^{\text {th }}$ sire

$\mathbf{S e}_{\mathbf{j}}=$ the fixed effect of the $\mathrm{j}^{\text {th }}$ season of birth (winter, summer);

$\mathbf{Y}_{\mathbf{k}}=$ the fixed effect of the $k^{\text {th }}$ year of birth $(1968,1969,1970 \ldots$ and 1981);

$\mathbf{e}_{\mathrm{ijkm}}=$ residual error assumed as random .

\section{RESULTS AND DISCUSSION}

\section{Sire effect:}

Analyses of variance showed that sire had significant effect on all productive traits except for LP and DP (Table 3) and also on reproductive traits except for AFC. Several workers have shown that productive and reproductive traits are heritable and they are greatly influenced sire (Petrovic, 1992, Ali, 1995 and Ali and El-Banna, 2001). Genetic improvement could be also achieved on these traits through sire selection.

\section{Environmental factors:}

The unadjusted overall mean \pm standard deviation of total milk yield (TMY) was $4056 \pm 1112 \mathrm{~kg}, 305-\mathrm{d}$ milk yield (305-dMY) was $3860 \pm 959 \mathrm{~kg}$, fat percentage (FP\%) was $3.69 \pm 0.16$, lactation period (LP) was $307 \pm 58.4$ days, dry period (DP) was $79.3 \pm 37.7$ days, fat yield (FY) was $150 \pm 40.7 \mathrm{~kg}$, fatcorrected milk was $3865 \pm 1051 \mathrm{~kg}$, annualized milk yield was $3861 \pm 991 \mathrm{~kg}$, calving interval $(\mathrm{Cl})$ was $386 \pm 62.9$ days, days open (DO) was $103 \pm 63.1$ days and age at first calving (AFC) was $871 \pm 110$ days (Table 1 ). TMY in the $3^{\text {rd }}$ lactation was significantly higher than that in the $2^{\text {nd }}$ and $1^{\text {st }}$ lactation by 11.5 
and $28.6 \%$, respectively (4689 VS 4205 and $3645 \mathrm{~kg}$, respectively). Each of $305 \mathrm{dMY}, \mathrm{FY}, \mathrm{FCM}$, and AMY followed the same trend of the TMY during the first three lactations (Table 1). Unadjusted overall mean of 305-dMY gradually increased to achive the highest in the third lactation $(4455 \mathrm{Kg})$. overall unadjusted mean of FP recorded same value in first, second, third and all lactation (3.7\%). The high coefficient of variation in both DP and DO during the three lactations ( 45.5 to $50.2 \%$ for DP and 62.0 to $62.3 \%$ for DO) reflects the great variation in the cow of this herd regarding these traits (Table 1).

Table 1: Unadjusted means(X) standard division (S.D) and coefficients of variation (C.V \%) of studied productive on and reproductive traits during the first three lactations.

\begin{tabular}{|c|c|c|c|c|c|c|c|c|c|c|}
\hline \multirow[t]{2}{*}{ Trait $^{\star}$} & \multicolumn{2}{|c|}{$\begin{array}{c}1^{\text {st }} \text { lactation } \\
(n=819)\end{array}$} & \multicolumn{2}{|c|}{$\begin{array}{c}2^{\text {nd }} \text { lactation } \\
(n=593)\end{array}$} & \multicolumn{2}{|c|}{$\begin{array}{c}3^{\text {rd }} \text { lactation } \\
(n=392)\end{array}$} & \multicolumn{4}{|c|}{$\begin{array}{c}\text { All lactations } \\
(n=1809)\end{array}$} \\
\hline & $X \pm S . D$ & CV\% & $X \pm$ S.D & $\mathrm{CV} \%$ & $X \pm S . D$ & $\mathrm{CV} \%$ & $X \pm S . D$ & CV\% & Max & Min \\
\hline \multicolumn{11}{|c|}{ Productive traits } \\
\hline TMY & $3645 \pm 959$ & 26.3 & $4205 \pm 1107$ & 26.3 & $4689 \pm 1063$ & 22.7 & $4056 \pm 1112$ & 27.4 & 9225 & 155 \\
\hline 305-dMY & $3459 \pm 809$ & 23.4 & $4020 \pm 934$ & 23.2 & $4455 \pm 905$ & 20.3 & $3860 \pm 959$ & 24.8 & 8755 & 1155 \\
\hline FP\% & $3.69 \pm 0.16$ & 4.37 & $3.70 \pm 0.16$ & 4.41 & $3.69 \pm 0.17$ & 4.73 & $3.69 \pm 0.16$ & 4.46 & 4.90 & 3.0 \\
\hline LP & $308 \pm 59.0$ & 19.2 & $303 \pm 60.5$ & 20.0 & $312 \pm 53.1$ & 17.0 & $307 \pm 58.4$ & 19.0 & 588 & 174 \\
\hline DP & $76.9 \pm 35.0$ & 45.5 & $82.4 \pm 41.4$ & 50.2 & $79.6 \pm 36.7$ & 46.1 & $79.3 \pm 37.7$ & 47.5 & 294 & 10 \\
\hline FY & $134 \pm 34.8$ & 26.0 & $155 \pm 40.7$ & 26.2 & $173 \pm 38.7$ & 22.4 & $150 \pm 40.7$ & 27.2 & 346 & 42 \\
\hline FCM & $3471 \pm 903$ & 26.0 & $4013 \pm 1050$ & 26.2 & $4465 \pm 1001$ & 22.4 & $3865 \pm 1051$ & 27.2 & 8879 & 1094 \\
\hline AMY & $3489 \pm 861$ & 24.7 & $4012 \pm 972$ & 24.2 & $4409 \pm 959$ & 21.7 & $3861 \pm 991$ & 25.7 & 8723 & 1059 \\
\hline & \multicolumn{10}{|c|}{$\begin{array}{c}\text { Reproductive traits } \\
\text { Reg }\end{array}$} \\
\hline CI & $385 \pm 63.3$ & 16.4 & $383 \pm 61.7$ & 16.1 & $393 \pm 64.2$ & 16.3 & $386 \pm 62.9$ & 16.3 & 585 & 300 \\
\hline DO & $102 \pm 63.5$ & 62.1 & $99.2 \pm 61.8$ & 62.3 & $110 \pm 64.3$ & 58.6 & $103 \pm 63.1$ & 61.3 & 300 & 20 \\
\hline AFC & $871 \pm 110$ & 12.6 & & & & & & & & \\
\hline
\end{tabular}

${ }^{\text {*TMY }}$ = total milk yield $(\mathrm{kg}), 305-\mathrm{dMY}=$ 305-day milk yield (kg), LP = lactation period (day), $\mathrm{DP}=$ dry period (day), FP\% = fat percentage, $F Y=$ fat yield $(\mathrm{kg}), \mathrm{FCM}=$ fat corrected milk (4\%) ( $\mathrm{kg}), \mathrm{AMY}=$ annualized milk yield $(\mathrm{kg}), \mathrm{Cl}=$ calving interval (day), DO = days open (day) and AFC = age at first calving (day).

Comparing the results of the present study with other investigations, Abou-Ela et al. (2001) found that TMY in the $1^{\text {st }}, 2^{\text {nd }}$ and $3^{\text {rd }}$ lactations were 7079, 7332 and $7526 \mathrm{~kg}$, respectively on Holstein Friesian cattle in Hungary which were high than the estimates reported in the present study. Detilleux et al. (1997) reported that dry period ranged from 40-135 day on Holstein Friesian in U.S.A. These differences may be due to many environmental factors such as used number of animals, method used of statistical analyses, climate, nutrition and other management conditions as well as differences in genetic composition from herd to another.

The generalized least squares means \pm standard errors of TMY was $4144 \pm 56.9 \mathrm{~kg}, 305-\mathrm{dMY}$ was $3971 \pm 48.3 \mathrm{~kg}$, FP was $3.71 \pm 0.01$, LP $308 \pm 1.58$ was days, DP was $81.4 \pm 1.25$ days, FY was $154 \pm 2.09 \mathrm{~kg}$, FCM was $3961 \pm 54.0 \mathrm{~kg}$, AMY was $3902 \pm 55.9 \mathrm{~kg}$, Cl was $390 \pm 3.88$ days, DO was $107 \pm 3.79$ days and AFC was $882 \pm 4.61$ days (Tables 2, 4 and 6). 
Oudah, E. Z. M. et al

Table 2: Least squares means and standard error ( \pm S.E) for productive traits as affected by different factors $(n=1809)$.

\begin{tabular}{|c|c|c|c|c|c|c|c|c|c|}
\hline Classification & No. & TMY & $\%$ & 305-dMY & $\%$ & FP & $\%$ & LP & $\%$ \\
\hline Overall mean & 1809 & $4144 \pm 56.9$ & & $3971 \pm 48.3$ & & $3.71 \pm 0.01$ & & $308 \pm 1.58$ & \\
\hline \multicolumn{10}{|c|}{ Season of calving } \\
\hline Winter & 771 & $4191 \pm 66.9$ & 100 & $4009 \pm 56.5$ & 100 & $3.71 \pm 0.01$ & 100 & $310 \pm 2.51$ & 100 \\
\hline Summer & 1038 & $4097 \pm 65.8$ & 98 & $3933 \pm 55.6$ & 98 & $3.72 \pm 0.01$ & 100 & $306 \pm 2.42$ & 99 \\
\hline \multicolumn{10}{|c|}{ Year of calving } \\
\hline 1971 & 46 & $4112 \pm 372$ & 91 & $3613 \pm 310$ & 85 & $3.80 \pm 0.07$ & 99 & $348 \pm 20.5$ & 98 \\
\hline 1972 & 108 & $4252 \pm 303$ & 94 & $3700 \pm 252$ & 87 & $3.83 \pm 0.05$ & 100 & $354 \pm 16.6$ & 100 \\
\hline 1973 & 136 & $4445 \pm 249$ & 98 & $4032 \pm 208$ & 94 & $3.76 \pm 0.04$ & 98 & $338 \pm 13.6$ & 95 \\
\hline 1974 & 149 & $4517 \pm 206$ & 100 & $4116 \pm 172$ & 96 & $3.72 \pm 0.04$ & 97 & $333 \pm 11.1$ & 94 \\
\hline 1975 & 190 & $4454 \pm 164$ & 99 & $4202 \pm 137$ & 98 & $3.71 \pm 0.03$ & 97 & $312 \pm 8.70$ & 88 \\
\hline 1976 & 223 & $4487 \pm 124$ & 99 & $4238 \pm 103$ & 99 & $3.67 \pm 0.02$ & 96 & $315 \pm 6.30$ & 89 \\
\hline 1977 & 192 & $4392 \pm 107$ & 97 & $4217 \pm 89.9$ & 99 & $3.66 \pm 0.02$ & 95 & $310 \pm 5.30$ & 88 \\
\hline 1978 & 170 & $4256 \pm 124$ & 94 & $4194 \pm 104$ & 98 & $3.65 \pm 0.02$ & 95 & $288 \pm 6.32$ & 81 \\
\hline 1979 & 162 & $4334 \pm 160$ & 96 & $4275 \pm 134$ & 100 & $3.66 \pm 0.03$ & 96 & $285 \pm 8.47$ & 81 \\
\hline 1980 & 133 & $4025 \pm 213$ & 89 & $4083 \pm 178$ & 96 & $3.65 \pm 0.04$ & 95 & $282 \pm 11.5$ & 80 \\
\hline 1981 & 116 & $3337 \pm 260$ & 74 & $3377 \pm 216$ & 79 & $3.76 \pm 0.05$ & 98 & $282 \pm 14.2$ & 80 \\
\hline 1982 & 114 & $3463 \pm 313$ & 77 & $3619 \pm 261$ & 85 & $3.73 \pm 0.05$ & 97 & $278 \pm 17.2$ & 79 \\
\hline 1983 & 70 & $3802 \pm 388$ & 84 & $3961 \pm 324$ & 93 & $3.65 \pm 0.07$ & 95 & $278 \pm 21.4$ & 79 \\
\hline \multicolumn{10}{|l|}{ Parity } \\
\hline 1 & 819 & $3564 \pm 87.3$ & 76 & \pm 73.3 & 78 & $3.68 \pm 0.01$ & 99 & $301 \pm 4.01$ & 95 \\
\hline 2 & 598 & $4169 \pm 64.3$ & 89 & $3999 \pm 54.4$ & 90 & $3.72 \pm 0.01$ & 100 & $306 \pm 2.30$ & 97 \\
\hline 3 & 392 & $4700 \pm 93.3$ & 100 & $4446 \pm 78.3$ & 100 & $3.73 \pm 0.02$ & 100 & $317 \pm 4.41$ & 100 \\
\hline \multicolumn{10}{|c|}{ Regression on days open } \\
\hline Linear & & $4.620 \pm 0.742$ & & $2.052 \pm 0.618$ & & $0.000 \pm 0.000$ & & $5 \pm 0.041$ & \\
\hline Quadratic & & $-0.005 \pm 0.008$ & & $-0.015 \pm 0.006$ & & $0.000 \pm 0.000$ & & $0.001 \pm 0.000$ & \\
\hline
\end{tabular}

Table 2: Cont.

\begin{tabular}{|c|c|c|c|c|c|c|c|c|c|}
\hline \multicolumn{2}{|c|}{ Classification No. } & DP & $\%$ & FY & $\%$ & FCM & $\%$ & AMY & $\%$ \\
\hline \multirow{2}{*}{\multicolumn{2}{|c|}{$\begin{array}{l}\text { Overall mean } 1809 \\
\text { Season of calving }\end{array}$}} & $81.4 \pm 1.25$ & & $154 \pm 2.09$ & & $3961 \pm 54.0$ & & $3902 \pm 55.9$ & \\
\hline & & & & & & & & & \\
\hline \multirow[t]{2}{*}{ Winter } & 171 & $82.7 \pm 1.93$ & 100 & $155 \pm 2.46$ & 100 & 4002 & & & \\
\hline & 1038 & $80.2 \pm 1.86$ & 97 & $152 \pm 2.41$ & 98 & $3921 \pm 62.4$ & 98 & & \\
\hline \multicolumn{10}{|c|}{ Year of calving } \\
\hline 1971 & 46 & $97.2 \pm 15.4$ & 97 & $155 \pm 13.7$ & 93 & $3976 \pm 352$ & 92 & $3456 \pm 348$ & \\
\hline 1972 & 108 & $99.8=$ & 100 & $161 \pm 11.1$ & 97 & & 96 & & \\
\hline 19 & 136 & 93.2 & 93 & $166 \pm 9.18$ & 100 & 427 & 99 & 3845 & \\
\hline & 149 & $90.7=$ & 91 & $167 \pm 7.57$ & 100 & 431 & 100 & & \\
\hline & 190 & 85.2 & 85 & $164 \pm 6.03$ & 98 & 424 & 98 & & 97 \\
\hline 19 & 223 & 78.9 & 79 & 164 & 98 & 425 & 99 & 416 & \\
\hline & 192 & 76.8 & 77 & 160 & 96 & & 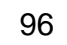 & & \\
\hline 19 & 170 & 78.1 & 78 & $155 \pm$ & 93 & 40 & 93 & $41 \varepsilon$ & \\
\hline & 162 & 83.1 & 83 & & 95 & & 5 & & \\
\hline 19 & 133 & 83.4 & 84 & $147 \pm 7.83$ & 88 & 381 & 88 & 397 & \\
\hline & 11 & 74.2 & 74 & & 75 & & 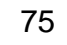 & & \\
\hline 19 & 114 & & 62 & & 78 & & 77 & & \\
\hline $19 \varepsilon$ & 70 & & 57 & & 84 & & 84 & 412 & \\
\hline \multicolumn{10}{|l|}{ Parity } \\
\hline 1 & 819 & $75.9 \pm$ & 90 & $131 \pm 3.21$ & 75 & & 75 & & \\
\hline 0 & 598 & $84.6 \pm$ & 100 & $155 \pm 2.36$ & 88 & & 89 & & \\
\hline & 392 & $83.7 \pm 3.34$ & 99 & .43 & 100 & 450 & & $4 ?$ & \\
\hline \multicolumn{10}{|c|}{ on days open } \\
\hline \multicolumn{3}{|r|}{$0.213 \pm 0.031$} & & $0.174 \pm 0.027$ & & 4.457 & & -3.2 & \\
\hline \multicolumn{2}{|l|}{ Quadratic } & $0 \pm 0.000$ & & & & $0.005 \pm 0.007$ & & $0.000 \pm 0.007$ & \\
\hline
\end{tabular}




\section{Season of calving/birth:}

Analyses of variance presented showed that season of calving/birth had insignificant effect on all productive (Table 3 ) and reproductive (Tables 5 and 7) traits. Ali (1995) and Tag El-Dein (1997) in Friesian cow, found that season of calving had no significant effect on Cl. Darwash et al. (1997) reported that there was no significant effect of season on DO (spring 84.8, summer 90.6, autumn 87.9 and winter 85.3 day) in British Friesian cows. These results are in agreement with those reported in the present study.

Table 3: Analysis of variance for factors affecting productive traits.

\begin{tabular}{|c|c|c|c|c|c|c|c|c|c|}
\hline \multirow{2}{*}{ S.V } & \multirow{2}{*}{ D.F. } & \multicolumn{8}{|c|}{ F-value and significance* } \\
\hline & & TMY & M305 & FP & LP & DP & FY & FCM & AMY \\
\hline Sire & 35 & $1.79^{\star *}$ & $1.69^{* *}$ & $1.69^{* *}$ & $0.72^{\mathrm{NS}}$ & $0.95^{\mathrm{NS}}$ & $1.79^{* *}$ & $1.80^{* *}$ & $2.00^{* *}$ \\
\hline Dam within sire & 712 & $1.62^{* \star}$ & $1.83^{\star *}$ & $1.3^{* \star}$ & $0.91^{\mathrm{NS}}$ & $1.09^{\mathrm{NS}}$ & $1.60^{\star *}$ & $1.61^{\star \star}$ & $1.54^{* *}$ \\
\hline Season of calving & 1 & $1.9^{\mathrm{NS}}$ & $1.79^{\mathrm{NS}}$ & $0.96^{\mathrm{NS}}$ & $S 1.2^{N S}$ & $0.74^{\mathrm{NS}}$ & $1.36^{\mathrm{NS}}$ & $1.58^{\mathrm{NS}}$ & $0.42^{N S}$ \\
\hline Year of calving & 12 & $4.59^{\star *}$ & $6.82^{* *}$ & $4.23^{\star \star}$ & $2.04^{*}$ & $1.34^{\mathrm{NS}}$ & $3.46^{* *}$ & $3.93^{\mathrm{NS}}$ & $5.04^{* *}$ \\
\hline Parity & 2 & $35.5^{* *}$ & $38.2^{* *}$ & $3.34^{*}$ & $2.62^{\mathrm{NS}}$ & $4.4^{*}$ & $38.9^{\star *}$ & $37.8^{\star *}$ & $23.5^{* *}$ \\
\hline \multicolumn{10}{|c|}{ Regression on days open: } \\
\hline Linear & & $38.8^{* *}$ & $11.0^{\star *}$ & $0.15 \mathrm{NS}$ & S $138^{* *}$ & $46.9^{\star \star}$ & $40.5^{\star *}$ & $40.2^{* *}$ & $21.8^{* *}$ \\
\hline atic & & $0.37^{N S}$ & $5.82^{*}$ & $0.39^{N S}$ & $2.27^{N S}$ & $0.71^{\mathrm{NS}}$ & $0.54^{\mathrm{NS}}$ & $0.47^{\mathrm{NS}}$ & $0.00^{\mathrm{NS}}$ \\
\hline Reminder & 1044 & & & & & & & & \\
\hline
\end{tabular}

Table 4: Least squares means and standard error ( \pm S.E) for calving interval ( $\mathrm{Cl}$, day) and days open (DO, day) as affected by different factors

\begin{tabular}{|c|c|c|c|c|c|}
\hline $\begin{array}{l}\text { Classification } \\
\text { Overall mean }\end{array}$ & $\begin{array}{c}\text { No. } \\
1809\end{array}$ & $\begin{array}{c}\text { Cl } \\
390 \pm 3.88\end{array}$ & $\%$ & $\begin{array}{c}\text { DO } \\
107 \pm 3.79\end{array}$ & $\begin{array}{c}\% \\
1809\end{array}$ \\
\hline Winter & 771 & $388 \pm 4.30$ & 99 & $105 \pm 4.22$ & 96 \\
\hline Summer & 1038 & $392 \pm 4.23$ & 90 & $109 \pm 4.15$ & 100 \\
\hline 1971 & 46 & $433 \pm 19.5$ & 100 & $153 \pm 19.47$ & 100 \\
\hline 1972 & 108 & $423 \pm 15.9$ & 98 & $141 \pm 15.89$ & 92 \\
\hline 1973 & 136 & $417 \pm 13.2$ & 96 & $135 \pm 13.18$ & 88 \\
\hline 1974 & 149 & $393 \pm 11.0$ & 91 & $111 \pm 11.00$ & 73 \\
\hline 1975 & 190 & $374 \pm 8.89$ & 86 & $91.9 \pm 8.86$ & 60 \\
\hline 1976 & 223 & $371 \pm 6.89$ & 86 & $88.1 \pm 6.85$ & 58 \\
\hline 1977 & 192 & $374 \pm 6.11$ & 86 & $90.3 \pm 6.06$ & 59 \\
\hline 1978 & 170 & $371 \pm 6.89$ & 86 & $87.1 \pm 6.85$ & 57 \\
\hline 1979 & 162 & $378 \pm 8.71$ & 87 & $94.5 \pm 8.68$ & 62 \\
\hline 1980 & 133 & $389 \pm 11.4$ & 90 & $105 \pm 11.3$ & 69 \\
\hline 1981 & 116 & $390 \pm 13.8$ & 90 & $106 \pm 13.8$ & 69 \\
\hline $\begin{array}{l}1982 \\
1983\end{array}$ & $\begin{array}{l}114 \\
70\end{array}$ & $\begin{array}{l}380 \pm 16.5 \\
376+203\end{array}$ & $\begin{array}{l}88 \\
87\end{array}$ & $\begin{array}{l}96.0 \pm 16.5 \\
909+20.4\end{array}$ & $\begin{array}{l}63 \\
59\end{array}$ \\
\hline Parity & & & & & \\
\hline 1 & 819 & $388 \pm 5.28$ & 98 & $106 \pm 5.21$ & 95 \\
\hline 2 & 598 & $387 \pm 4.18$ & 98 & $103 \pm 4.09$ & 92 \\
\hline & 392 & $395 \pm 5.54$ & 100 & $112 \pm 5.49$ & 100 \\
\hline \multicolumn{6}{|c|}{ Regression on: days open } \\
\hline Linear & & $0.011 \pm 0.002$ & & $0.011 \pm 0.002$ & $0.011 \pm 0.002$ \\
\hline Quadratic & & $0.000 \pm 0.000$ & & $0.000 \pm 0.000$ & $0.000 \pm 0.000$ \\
\hline
\end{tabular}




\section{Oudah, E. Z. M. et al}

\section{Year of calving/birth:}

Year of calving/birth showed significant effects on all studied productive (Table 3 ) and reproductive (Tables 5 and 7) traits except for DP and FCM. For example, the highest TMY occurred in $1974(4517 \mathrm{~kg})$ and lowest occurred in 1981(3337 kg) (Table 2). The results obtained in the present study are in agreement with the findings obtained by other investigators, e.g. Oudah et al. (2000). The effects of this are a result of the interaction of a set of environmental, technical and administrative management practices that make its interpretation difficult; however, it is an important source of variation that must be considered in the statistical analysis in order to better interpret of results. Additionally. Year of calving have been recognized as an important factor affecting milk yield in dairy cows. Most of results attributed the difference in milk yield to year of calving. The present results indicate that the changes in milk production from year to another may be due to the changes in management and climatic conditions from year to year which consequently affect the phenotypic trend of milk production. On the other hand, Amin et al. (1996) did not show any significant effect of year of calving on TMY of Holstein Friesian cattle.

\section{Parity number:}

Concerning the effect of parity on productive and reproductive performance of Black Pied cows used in the present study, analyses of variance showed that parity had significant effect on all productive traits except for LP (Table 3) and it was also significant on $\mathrm{Cl}$ (Table 5). Least squares means of TMY, 305-dMY, FY, FCM and AMY were increased obvious with increase of lactation order. Ashmawy and Khattab (1991) working on 1619 lactation records of Friesian cows, noticed that the effect of parity on AMY was significant $(P<0.01)$, and the AMY increased with the increase in the order of lactation. Tong et al. (1979) found that FY of $1^{\text {st }}, 2^{\text {nd }}$ and $3^{\text {rd }}$ lactation of Holstein were 180,206 and $255 \mathrm{~kg}$, respectively. Thomas (1980) analyzed data of 177 and Red Dane in $1^{\text {st }}$ and $2^{\text {nd }}$ lactation, respectively. He found that the FY were 158.9 for $1^{\text {st }}$ lactation and $184.5 \mathrm{Kg}$ for $2^{\text {nd }}$ lactation. Parity had no significant effect on FP; Stenzel (1980) studied the first three lactations for 717 Polish Black and White lowland as well as 201 Polish Red and White lowland cows. He found that the average FP were $3.89 \%$ in the $1^{\text {st }}$ lactation and increased to $3.96 \%$ in the $2^{\text {nd }}$ lactation, and then it declined to $3.94 \%$ in the $3^{\text {rd }}$ lactation for the first breed, while it was $3.69,3.87$ and $3.87 \%$ for the same lactations for the second breed. The present results are in agreement with Tag El-Dein (1997) who reported that parity had non-significant effect on lactation length for Friesian cows. EL-Awady (1998) using Friesian cows in Egypt, noticed that parity had highly significant effected on 305-DMY. Shitta et al. (2002) found that parities had highly significant effect on DO. Ganah (2000) and Gabr (2005) found no significant effect on $\mathrm{Cl}$ which is in agreement with the results obtained in the present study. On the other hand, Parity had no significant effect on dry period as reported by Rege et al. (1994) and Kassab (1995) who found nonsignificant differences among lactations in DP. 


\section{Regression coefficients:}

Analyses of variance showed that partial regression coefficients of all studied productive traits on DO were positive (Table 2) and significant (Table 3 ) except for AMY was negative and for FP was not significant. Meanwhile, the corresponding quadratic coefficients were not significant except for 305dMY (Table 3). Regarding the linear and quadratic regression coefficients of reproductive traits, i.e. $\mathrm{Cl}$ and DO on TMY, the results show that the linear regression coefficients of $\mathrm{Cl}$ and DO on TMY were also positive (Table 4) and significant (Table 5) meanwhile, the quadratic coefficients were not significant. Hageman et al. (1991), Ganah (2000) reported highly significant linear regression of $\mathrm{Cl}$ on milk yield, while they recorded non-significant quadratic regression for this relationship. Sweify (1997) did not find significant effect of DO length (131.7 vs. 136.6 days for high and low yield, respectively) on milk yield of Friesian cows in Egypt. The positive relationship between total milk yield and DO (poor fertility) may be attributed to the large deficient in energy balance that occurs in high producing dairy cows, especially during the first stage of lactation. Salem and Abdel-Raouf (1999) in Egypt found also that DO significantly $(P<0.01)$ affect 305-DMY. Ali et al. (2002) indicated that days open had highly significant effect on305-DMY. El-Sheikh (1995) found that the regression coefficient of lactation length on days open had highly significant $(P<0.01)$ effect at linear and quadratic values. On the other hand, Nenadovic et al. (1980) analyzed the milk records of 270 Holstein- Friesian heifers. They observed that days open averaged 135.8 days, and a negative correlated between the average milk FP and days open was also found for the whole lactation $(-0.31)$ and for 305 days $(-0.13)$.

Table 5: Analysis of variance for factors affecting calving interval $(\mathrm{Cl}$, day) and days open (DO, day) during across lactation.

\begin{tabular}{|c|c|c|c|c|c|}
\hline \multirow[b]{2}{*}{ S.V } & \multirow[b]{2}{*}{ D.F. } & \multicolumn{2}{|c|}{$\mathbf{C l}$} & \multicolumn{2}{|c|}{ DO } \\
\hline & & $\mathbf{F}$ & Prop. & $\mathbf{F}$ & Prop. \\
\hline Sire & 35 & 2.00 & $0.001^{* *}$ & 1.92 & $0.001^{* *}$ \\
\hline Dam within sire & 712 & 2.76 & $0.000^{\star *}$ & 2.78 & $0.000^{* *}$ \\
\hline Season of calving & 1 & 1.36 & $0.243^{N S}$ & 1.59 & $0.207^{N S}$ \\
\hline Year of calving & 12 & 4.33 & $0.000^{* *}$ & 4.39 & $0.000 * *$ \\
\hline Parity & 2 & 2.41 & $0.091 \mathrm{NS}$ & 3.97 & $0.019^{*}$ \\
\hline \multicolumn{6}{|c|}{ Regression on Total milk yield } \\
\hline Linear & 1 & 40.4 & $0.000^{* *}$ & 41.0 & $0.000^{\star *}$ \\
\hline Quadratic & 1 & 0.82 & $0.364 \mathrm{NS}$ & 0.95 & $0.331 \mathrm{NS}$ \\
\hline Reminder & 1044 & & & & \\
\hline
\end{tabular}


Oudah, E. Z. M. et al

Table 6: Least squares means and standard error ( \pm S.E) for age at first calving (AFC, day) as affected by different factors

\begin{tabular}{lccc}
\hline Classification & N.O & AFC & $\%$ \\
\hline Overall mean & 819 & $882 \pm 4.61$ & \\
Season of birth & & & \\
Winter & 431 & $883 \pm 5.87$ & 100 \\
Summer & 388 & $881 \pm 6.24$ & 100 \\
Year of birth & & & \\
1968 & 16 & $995 \pm 28.8$ & 100 \\
1969 & 59 & $880 \pm 18.3$ & 88 \\
1970 & 73 & $840 \pm 16.9$ & 84 \\
1971 & 59 & $867 \pm 18.2$ & 87 \\
1972 & 75 & $859 \pm 14.8$ & 86 \\
1973 & 108 & $843 \pm 11.9$ & 85 \\
1974 & 68 & $836 \pm 14.3$ & 84 \\
1975 & 76 & $898 \pm 15.1$ & 90 \\
1976 & 64 & $870 \pm 15.2$ & 87 \\
1977 & 57 & $850 \pm 15.6$ & 85 \\
1978 & 64 & $897 \pm 16.2$ & 90 \\
1979 & 58 & $896 \pm 17.4$ & 90 \\
1980 & 33 & $924 \pm 22.1$ & 93 \\
1981 & 9 & $895 \pm 37.3$ & 90 \\
\hline
\end{tabular}

Table 7: Analysis of variance for factors affecting age at first calving (AFC, day)

\begin{tabular}{lccc}
\hline & & \multicolumn{2}{c}{ AFC } \\
S.V & D.F. & F & Prop. \\
\hline Sire & 35 & 0.87 & $0.684^{\text {NS }}$ \\
Season of birth & 1 & 0.03 & $0.858^{\text {NS }}$ \\
Year of birth & 13 & 4.09 & $0.000^{* *}$ \\
Reminder & 767 & & \\
\hline
\end{tabular}

\section{Conclusion}

The results of the present study indicated that the parity and sire have highly significant effects on most of the productive traits. Therefore, more attention should be given to cows in the first parity in order to improve the productivity of the cows. Genetic improvement could be also achieved on these traits through sire selection.

\section{Acknowledgement}

The authors would like to thank E. Omarof, the ex-director of Chinaz Farm, Chinas, Uzbekistan for providing the data used in the present study

\section{REFERENCES}

Aboul-Ela, M.B.; Mostafa, M.A. and Shalaby, N.A. (2001). Association between productive and reproductive performance on Holstein Friesian herd in Hungary. J. Agric. Sci. Mansoura Univ., 26 (1): 207 - 216. 
Ali, H.M. (1995). Studies on cattle. Genetically and non-genetically factors affecting performance traits in Friesian cattle in Egypt. Ph.D. Thesis, Fac. of Agric., Alex. Univ., Egypt.

Ali, H.M and M.K. El-Banna. (2001). Genetic and phenotypic parameters for milk fat and protein percentage and 305-day milk production in Friesian cows. J. Agric. Sci., Mansoura Univ., 26 (4): 1923.

Ali, H.M., S.A. Ibrahim, Zenat B. Rabie, Zeianb A. Khalifa and K, Hussein. (2002). Effects of previous days open, previous days dry and current days open on milk production in Friesian cows. J. Agric. Sci., Mansoura Univ., 27 (2): 971.

Amin, A.A., S. Toth and Y. Gere (1996). Selection indices for improvement milk and fat yield based on age at first mating and calving under Hungarian conditions. Arch. Tierz., Dummerstorf 39: 25.

Ashmawy, A.A. and A.S. Khattab (1991). Factors affecting annualized milk yield in Friesian cows in Egypt. Egypt J. Anim. Prod., 28 (1): 1.

Darwash, A. O.; G. E. Lamming and J. A. Woolliams (1997). The phenotypic association between the interval to postpartum ovulation and traditional measures of fertility in dairy cattle. J. Anim. Sci., 65: 9.

Detilleux, J.C., Y.T. Grohn and R.L. Quaas (1997). Effects of Left displaced abomasum on test day milk yields of Holstein cows. J. Dairy Sci., 80: 121.

Dmitriez, N.G. and Ernst, L.K. (1989) Animal Genetic Resources of the USSR. Animal Production and Health Paper Publ. by FAO, Rome, 517 pp.

El-Awady, H.G.(1998). Genetical analysis of reproductive and productive performance of Friesian herds. Ph.D. Thesis, Fac. Agric., Kafr ElSheikh, Tanta Univ., Egypt.

El-Sheikh, S.M. (1995). Some productive and reproductive traits of dairy Friesian cows under Sakha condition. Ph.D. Thesis, Fac. of Agric., Cairo Univ., Egypt.

Gabr, A.A.A. (2005). Evaluation of some economic traits of Friesian cows in Egypt. M.Sc. Thesis, Fac. of Agric., Mansoura Univ., Egypt.

Gaines, W. L., O. R. Overman. (1938) Interrelations of Milk-Fat, Milk-Protein and Milk-Energy Yield. J. Dairy Sci. 21: 261-271

Ganah, H. A. B. (2000). Effect of improved management systems on prodactivity of Friesian cattle. M. Sc. Theses Fac., of Agric. Mansoura University, Mansoura, Egypt.

Hageman, W.H., G.E. Shook and W.J. Tyier (1991). Reproductive performance in genetic lines selected for high or average milk yield. J. Anim. Sci., 74: 4366.

Harvey, W.R. (1990). User's Guide For LSMLMW, Mixed Model Least Squares Program. PC-2 Version. Ohio State. University, Columbus (Mimeograph), USA.

Kassab, M.S. (1995). Factors affecting some performance traits in Friesian cattle. Alex. J. Agric. Res. 40(1): 65-76.

Million, T. and D. Tadelle (2003) Milk production performance of Zebo , Holstein Friesian and their crosses in Ethiopia.Livestock Research for Rual Development (15)3:1:11. 
Nenadovic, M .; V. Karadzic; S. Gavrilovic; B. Stepanov and K. Krstic (1980). The relationship between service period duration and dairy performance of Holstein-Ferisian cow in their first lactation. Stocarstvo (1979) 33 (7-8) 219-227 (Sh, en, 15 ref.) Poljopriverdni fakultet, Novi. Sad. ,Yugoslavia (A. B. A.,45: 5, 2413, 1980).

Oudah, E.Z.M. (1996). Breeding and economical efficiency of using Black Pied breed cows for a long time of production under hot climate condition in Uzbekistan. Ph.D. Thesis. Tashkent State Agrarian University, Tashkent, Uzbekistan (Manuscript in Russian).

Oudah, E.Z.M., N.A. Shalaby, and A.F.A. Mehrez, (2000). Genetic study on milk productive traits using first lactation records. Proceedings of 3rd All African Conference on Animal Agriculture and 11th Conference of the Egypt. Soc. Anim. Prod., Alexandria, November 6-9, 2000, Egypt, 689.

Petrovic, M. (1992). The effect of sire on phenotypic parameters of lifetimedairy performance of Friesian cows. Dairy Sci. Abst., 24: 7662.

Rege. J. E. O. and G. S. Aboagye, S. Akah and B. K. Ahunu (1994). Crossbreeding Jersey with Ghana shorthorn and Sokoto Gudali in atropical environment additive and heterotic effects for milk production, reproduction and calf groth traits.AnimProd., 59;21-29.

Salem, A.Y. and R.M. Abdel-Raouf (1999). Genetic study of fertility and reproductive traits in a commercial herd of Holstein Friesian cattle in Egypt. J. Agric. Res., Tanta Univ., Egypt 25: 191.

Shitta, A. A.; M. A. Tag El-Dien and Set El-Habaeib S. Awad (2002). A study on production and reproduction traits of Friesian cattle in Egypt. J. Agric., Sci. Mansoura Univ., 27(11):7281.

Stenzel, R. (1980). Changes in milk protein content of polish Black- and White and Red - and - White lowland cows according to the fat content, stage of lactation and season of calving. Annales Universitatis Mariae Curie - Sktodoweka, E Agriculture (1976, pupl. 1979) 31, 337351. (A. B. A.,48: 5, 2414, 1980).

Swiefy, A. S. M. (1997). Postpartum reproductive performance of Friesian cowsin relation to season of calving and level of milk production. Ph. D. Thesis, Fac. of Agric., Cairo Univ., Egypt.

Tag El-Dein, M.A. (1997). Studies on cattle. "Phenotypic and genetic parameters of some performance traits in Friesian cattle". Ph.D. Thesis, Fac. of Agric., Alex. Univ., Egypt.

Thomas, P. C. (1980). Genetic studies on economic traits of Red Dane cattel. Thesis abstracts Haryana Agric., Univ. (1977) 3 (1-2) 40-41(En) Agric., Sci., Univ. Bangalore, India, from A. B. A. (D. S. A., 42: 4,1873,1980).

Tong, A.K. W.; B.W. Kennedy and J. E. Moxley (1979). Heritabilities and genetic correlations for the first three lactations from records subject to culling. J. Dairy Sci., 62 : 1784- 1790. 


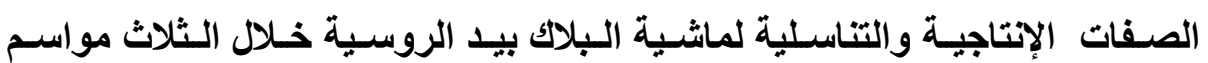

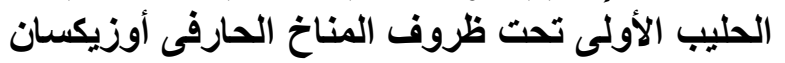

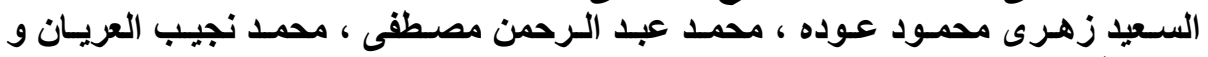
رحاب فوزى صديق عبد الفتاح إسماعيل ، إعيل قسم الإنتاج الحيواني- كلية الزئ علئ إعة - جامعة المنصورة

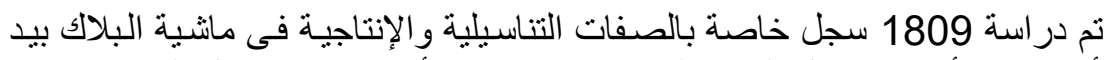

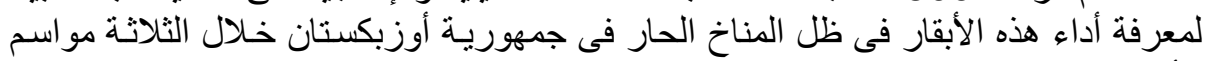

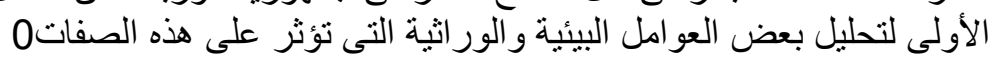

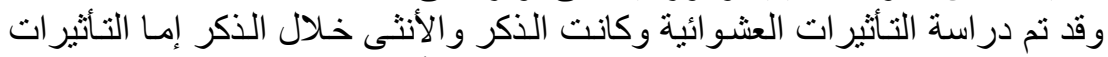

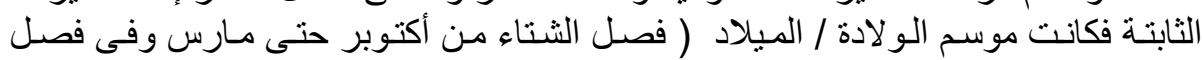

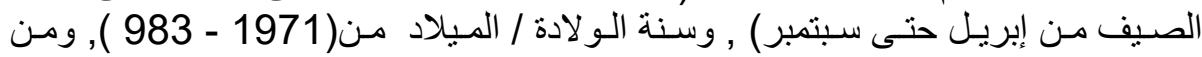

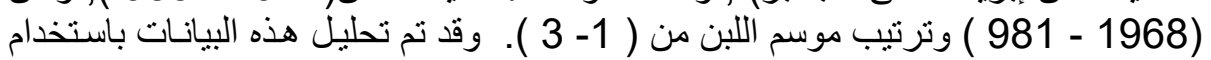

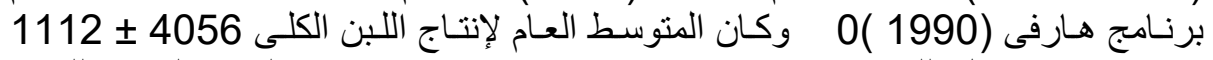

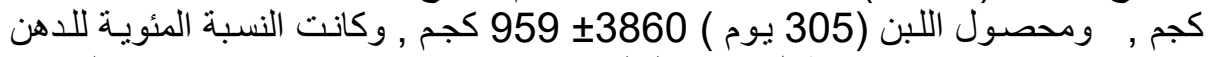

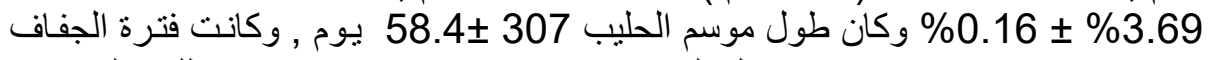

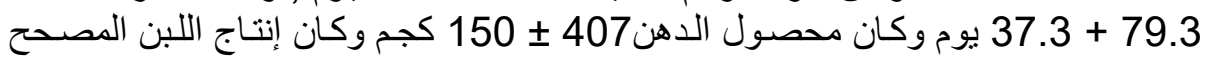

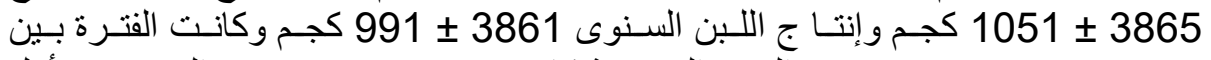

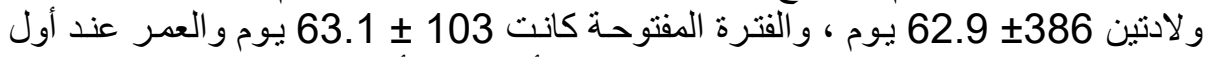

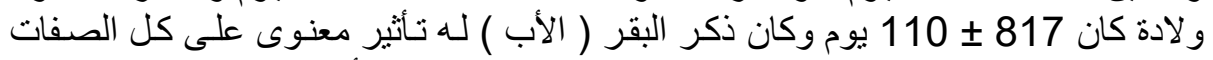

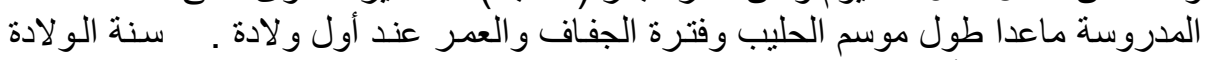

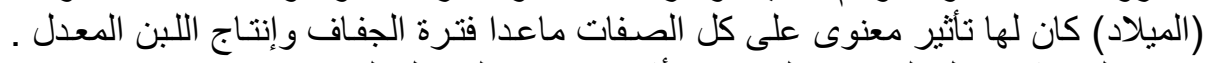

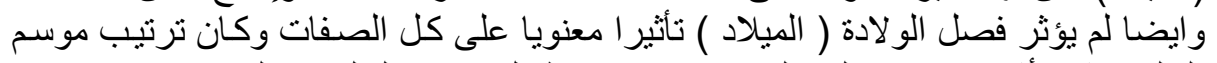

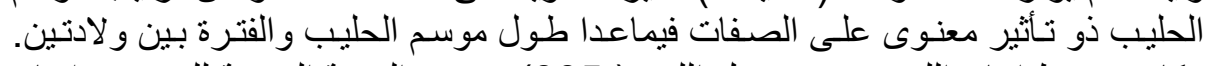

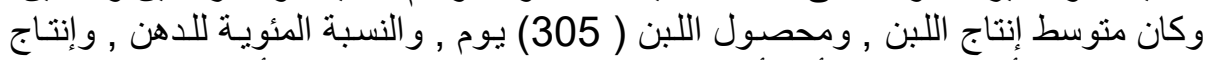

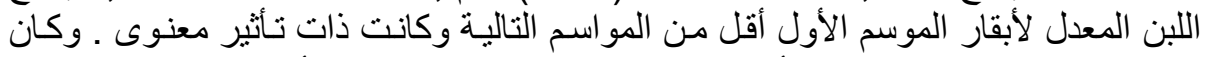

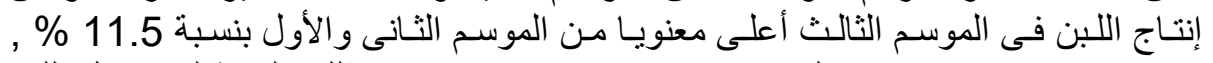

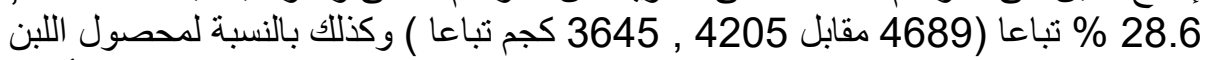

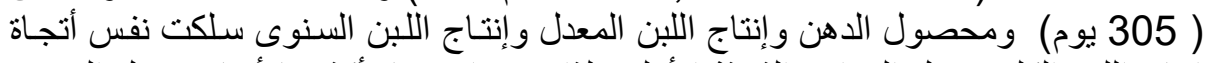

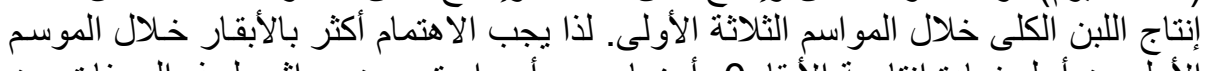

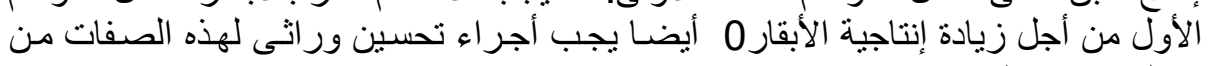

خلال انتخاب الذكور 0 